\title{
日本庭園における苑路歩行時の注視に関する研究
}

\section{A Research on a Gaze Time at the Garden Path Walk in Japanese Garden}

\author{
酒井 拓* 山本 聡** 前中 久行* \\ Taku SAKAI Satoshi YAMAMOTO Hisayuki MAENAKA
}

\begin{abstract}
A pedestrian's gaze action is related to the feature of a sequence scene. It is thought that there are some garden scene elements which determine the course selection, and that those elements would have shown high fixation frequencies. This research, in order to confirm this assumption, aimed at clarifying pedestrian's visual recognition character over the garden scene elements by using eye-mark recorder in a Japanese garden. The results are as followings: Average gaze time was $0.15 \mathrm{sec}-0.2 \mathrm{sec}$ through the whole scene elements, pedestrian's once gaze time was quite short, and there was no differences in the each scene elements. However, the total gaze time to the flat bridge and the surface of water were in a higher rank among all scene elements, except plant leaves. Former two scene elements belong to the most important category in the element which forms the Japanese gardens. Since these two scene elements were frequently appeared as course selection motives by the questionary survey, it can be said that the "bridge" and the "water surface" are bearing the important role visually in the Japanese gardens. The total gaze time of pedestrian to the artificial scene elements area was higher than those of natural elements area in the scene for experiment. These results lead to the conclusion that different nature scene elements against the natural elements, which were easy to be fixed eyes on, are major factor for course selection.
\end{abstract}

Keywords: Japanese garden, fixation, eye-mark recorder キーワード：日本庭園，注視，アイカメラ

\section{1.はじめに}

迴遊式庭園は苑路を歩行することによって多様な景観変化を体 験できる庭園形式である。多様な景観を形づくる構成要素として は苑路そのものや樹木に代表される植物, 橋や四阿などの人工構 造物, あるいは地形など多数挙げられる。これらの要素を意図的 に配置することにより变化に富んだ庭園が形づくられていると言 える。利用者の注視行動を通して人の庭園空間の捉えかたを解析 することは今後の庭園の計画設計に非常に有用である。

これら, 利用者の注視行動を扱った既存の研究は材野らの空間 構成の変化に対する利用者の反応を調查した研究 ${ }^{1)} や$ 仲山らのア ンケートを用いた利用実態・空間特性調査 ${ }^{2)}$ などがあるが，いず れもヒアリングや観察によるものであり, 歩行者の注視デー夕を 解析した研究ではない。回遊による視点移動が主な鑑賞行動とな る回遊式庭園における歩行者の注視デー夕をアイカメラはリアル タイムで記録し, 歩行者の景観構成要素に対する注視点及び注視 時間を明らかにできるため, 本研究の意義に最む沿う手段である と思わ机る。

この実験では都市公園の敷地に設けられた日本庭園内の苑路分 岐路を主要な調査対象区として, 分岐路が見え始める地点から歩 行者が経路選択に至るまでの注視デー夕を採取し, 景観の空間構 成と注視の特徵の関係から実験区間の注視特性を明らかにするこ とを目的とする。

\section{2. 研究方法}

(1) 調査の概要

本論文では, 苑路分岐路の空間構成の特徴を景観構成要素を自 然的要素之人工的要素の 2 つに大別し, さらに色感及び質感の違 いをあとに分類して明らかにした。また, 注視の特徴については 歩行者の注視点と, その注視対象に対する注視時間などの指標か ら明らかにした。

\section{（2）調査対象}

本調查は堺市の大仙公園内にある日本庭園で行った。本庭園の 庭園形式は築山林泉迴遊式である。

大仙公園日本庭園の平面図を図 1 に, 実験対象区の平面図を図 2 に示す。本論文がデータとして取り扱う区間は図 2 中のアイカ メラ解析区間である。調査対象区間は, 川が池に流れ込む河口に 分岐路が位置しており, 苑路を進むに従って空間の開放性が上昇 している。また歩行者の進行方向の景観には八橋型の平橋を始め として反り橋, 休憩所などの人工的要素が多数含まれている。

材野らの研究 ${ }^{3)}$ により歩行者の注視を伴う景観行動は空間の開 放度が上昇する地点において人工的要素とも関係して増加する傾 向がある事が分かっているため，上記区間が適切だと判断した。

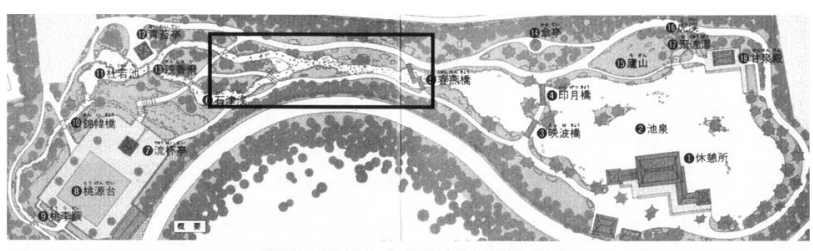

黒線で囲まれた部分が実験対象区

図-1 大仙公園日本庭園平面図

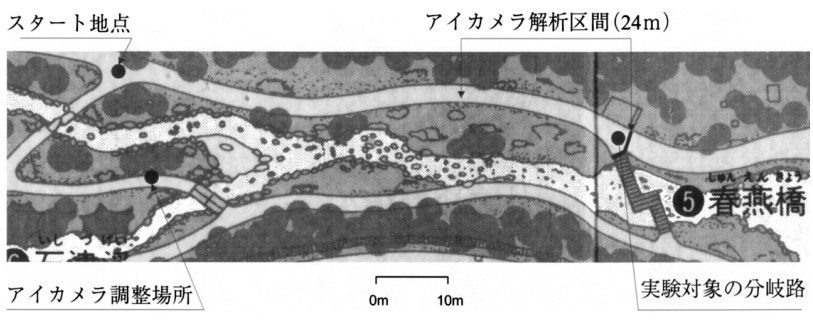

図 -2 実験区間平面図

*大阪府立大学大学院農学生命科学研究科 ${ }^{* *}$ 兵庫県立淡路景観園芸学校 /姫路工業大学自然 - 環境科学研究所 


\section{（3）調査方法}

対象区間に抢いて被験者はアイカメラのカメラ部分がついた帽 子を被り, アイカメラの調整器とバッテリー及び録画用の $8 \mathrm{~mm}$ デオカメラ（DCR-PC100）を収納したザックを背負って歩行し， アイカメラによって視線方向を記録した。同時に，ビデオカメラ を持った実験者が後方より随行し, 被験者の位置や頭部運動など を撮影した。視線解析を行うためのアイカメラはナック社製の EMR-8 型を使用した。

被験者は専門的教育を受けている大学の学生 6 人である。全被 験者と屯大仙公園の日本庭園を訪れるのは初めてであった。

実際には被験者にそれぞれ一回づつ対象区間を歩いてもらい, デー夕を取得した。その手順は以下の通りである。

まず，実験前に被験者が実験の対象となる景観を見ることによっ て何らかの影響が及ぶことを防ぐために, 被験者には下を見なが らアイカメラの調整を行う場所までついて来てもらい, 調整を行っ た。そして, 被験者を実験説明場所に連れて行き,「前方に見え る分岐路を右に曲がってから, 私が止めるまで自由に歩いて下さ い」之伝えた。その際, 被験者には実験の目的を知らせてはいな い。止める夕イミングは, 図 2 中の実験対象の分岐路において, 被験者が平橋か苑路のどちらかへ明らかに踏み込んだ時点である。 なお，この時点をむって注視デー夕の採取を終了した。

この歩行実験を終えた後, 実験対象景観が見えない場所へ被験 者を誘導し，描画実験及びヒアリングを行った。「今歩いた苑路 の中で印象に残っている風景を思い浮かべた順に描いてください。 その際，思った事を描いた風景の横に記述してください」と説明 した (描画実験)。次に, 分岐路に気付いた地点, 経路選択を決 定した地点について苑路平面図に記入してもらうとともに, 経路 選択の動機を記述してもらった。また, 描画実験で描かれた風景 がごこから見たものかについても平面図に記入してもらった。描 画実験後, 撮影したアイカメラの映像を見せながら, 歩行実験時 に考えていたことを被験者に質問した（ヒアリング）。

\section{（4）解析方法}

本実験において $1 / 60 \mathrm{sec}$ 毎のアイマークデータが得られた。 このデータを解析するに当たっては同一注視の判定基準を定める 必要がある。一般的に静止画像では注視の定義 ${ }^{4)}$ は「視野角 1 度 以内の停留範囲で, $0.2 \mathrm{sec}$ 以上の停留時間」とされているが歩行 実験では歩行に伴う上下左右の振動のために録画されるアイマー クデー夕も同様に振動する。そのためその振動の範囲を視野角に 含めて解析しなければならない。これに関しては鈴木ら5)の実験 結果を参考にして解析を行った。

鈴木らの実験内容は以下の通りである。廊下の突き当たりの壁 面に $5 \mathrm{~cm}$ 四方の黒色マークを一辺 $50 \mathrm{~cm}$ の正方形の各頂点に配慮 するように貼る。アイカメラを装着した被験者をそこから $30 \mathrm{~m}$ 離れた地点に立たせ, マークの方向に直進しながら時計回りに順 に注視するように教示する，というあのである。この実験からは $1 / 60 \sec$ あたりのアイマークの移動が視野角 2.9 度以内の場合を 同一注視とする基準が得られている。

本実験でもこの基準を用いた。また，注視時間については $0.05 \mathrm{sec}-0.2 \mathrm{sec}$ のあのあ抽出した。これは抽出された注視点の注 視時間が $0.1 \mathrm{sec}$ 台を中心としていたからである。アイマークデー 夕収集区間に扔いて記録されたアイマークデータから注視点を抽 出し, 各注視点の注視時間や分類した注視対象 (図 3 ) を記録し た。

人工的要素の分類項目「説明板」「樹木名板」は文字が表示さ れているため, 厳密に分類すると他の景観要素之は分けるべきで あるが, 説明板の解説表示は歩行者側からは見えず, 樹木名板に ついて屯実験対象景観において一つの視認対象物として事実上存 在するとの考えから今回の実験ではこれら 2 つを他の景観構成要
素とともに注視の対象物として取り扱った。なお，本実験では注 視点以外のアイマークデー夕は解析していない。

また，景観構成要素の面積占有率に対する注視時間の割合を求 めるために，アイマークデー夕収集開始点（分岐路が見え始める 地点）から調査対象の分岐路までの区間の間を始点から最大 $5 \mathrm{~m}$ 間隔で撮影点を計 6 つ設けた。

歩行によって視野内の景観構成要素の面積占有率は絶え間なく 变化する。本研究の実験区間の特性上アイカメラ解析区間の始点 之終点では各景観構成要素の面積占有率は大いに異なる。そのた め実験区間を幾つかの小さな区間に分けてそれぞれの各景観構成 要素の面積占有率を算出する必要がある。区間を最大 $5 \mathrm{~m}$ 間隔に 分けたのは, 進士 ${ }^{6)}$ が回遊式庭園は「約 $7 \mathrm{~m}$ をモ゙ュールとして 景観が変化する」と述べている。本実験ではこれよりも短い距離 として $5 \mathrm{~m}$ を採用した。

次に, 各撮影点に执いて, 進行方向に向かって水平方向 180 度 の景観をカバーする画像を，デジタルカメラを用いて地面から垂 直に撮影した 5 ないし 6 枚の写真画像をつなぎ合わせて構成し，

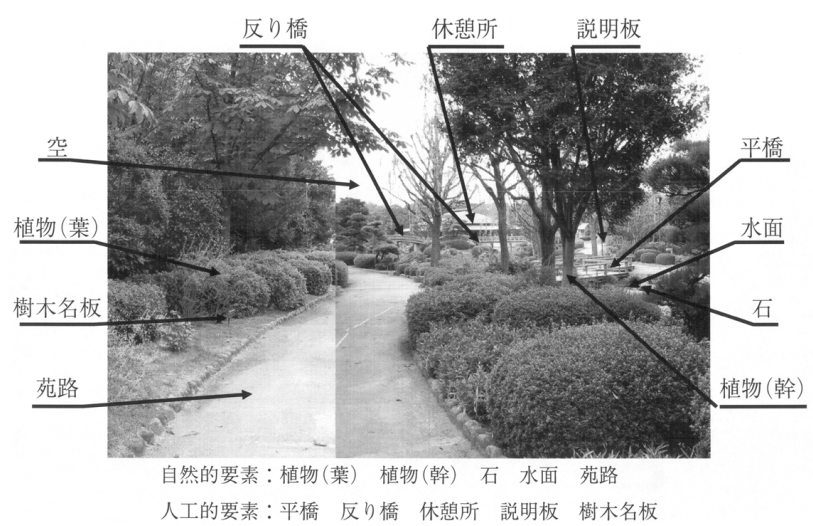

図-3 注視対象の分類

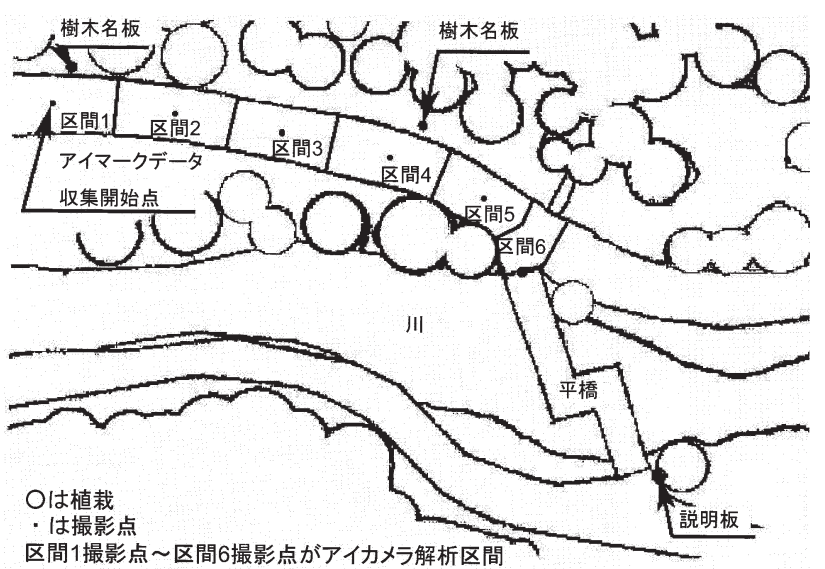

図-4 区間分類図

表 -1 被験者の歩行特性

\begin{tabular}{|c|c|c|c|c|}
\hline 被験者 & $\begin{array}{c}\text { 歩行時間 } \\
(\mathrm{sec})\end{array}$ & $\begin{array}{c}\text { 平均歩行速度 } \\
(\mathrm{m} / \mathrm{sec})\end{array}$ & $\begin{array}{l}\text { 注視 } \\
\text { 点数 }\end{array}$ & $\begin{array}{l}\text { 平均注視 } \\
\text { 時間(sec) }\end{array}$ \\
\hline A & 32.5 & 0.74 & 64 & 0.17 \\
\hline B & 27 & 0.89 & 79 & 0.15 \\
\hline $\mathrm{C}$ & 42 & 0.57 & 73 & 0.16 \\
\hline D & 21.5 & 1.12 & 11 & 0.15 \\
\hline E & 29 & 0.83 & 53 & 0.16 \\
\hline F & 26 & 0.92 & 22 & 0.16 \\
\hline
\end{tabular}




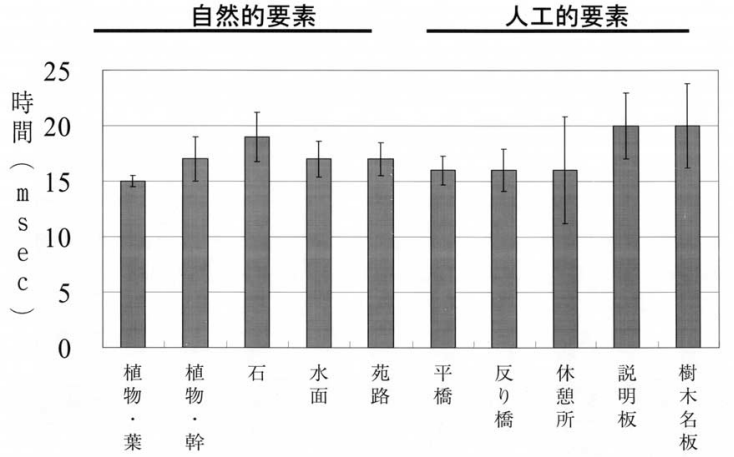

景観構成要素

図-5 総平均注視時間及び標準誤差

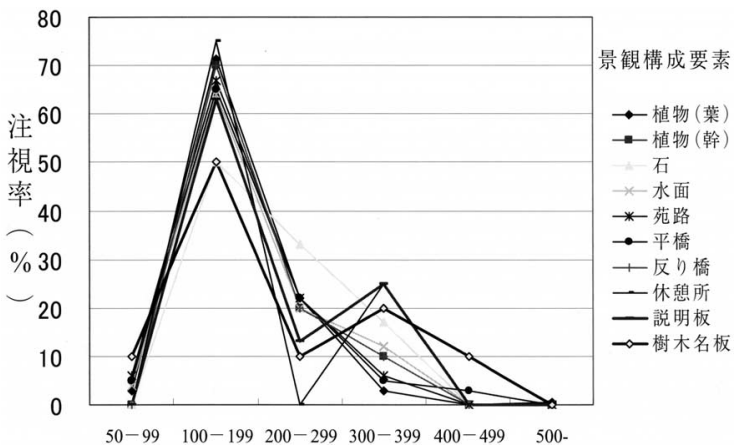

注視時間 $(\mathrm{msec})$

図-6 注視対象別注視頻度分布

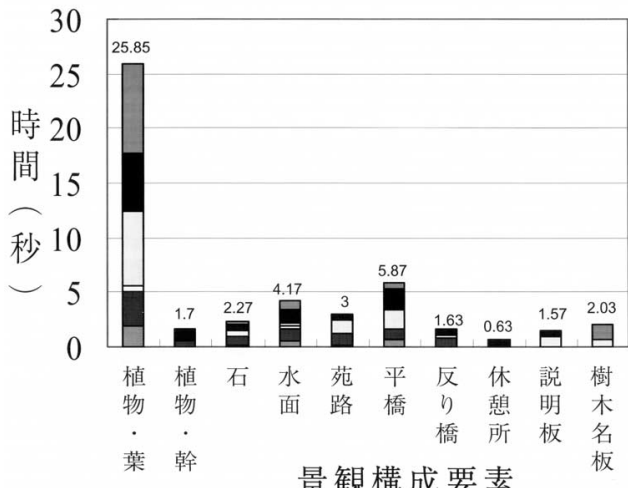

被験者

$\square \mathrm{A}$

- B

$\square \mathrm{C}$

$\square \mathrm{D}$

$\square \mathrm{E}$

$\square \mathrm{F}$

図-7 全被験者の総注視時間

表 -2 景観要素ごとの相対注視時間の区間比較

\begin{tabular}{c|cccccc}
\hline 景観構成要素 & \multicolumn{7}{|c}{ 実験区間 } \\
植物(葉) & 1 (1) & $(2)$ & $(3)$ & 4 & 5 & 6 \\
植物(幹) & 83 & 57 & 42 & 62 & 47 & 16 \\
石 & 0 & 8 & 2 & 1 & 0 & 0 \\
水面 & 0 & 7 & 7 & 5 & 8 & 54 \\
苑路 & 0 & 8 & 8 & 7 & 7 & 5 \\
平橋 & 1 & 14 & 13 & 7 & 21 & 0 \\
反り橋 & 0 & 3 & 3 & 7 & 4 & 1 \\
休憩所 & 0 & 2 & 4 & 0 & 0 & 0 \\
説明板 & 0 & 0 & 8 & 6 & 1 & 0 \\
樹木名板 & 8 & 0 & 11 & 1 & 0 & 0 \\
\hline & $100 \%$ & $100 \%$ & $100 \%$ & $100 \%$ & $100 \%$ & $100 \%$ \\
\hline
\end{tabular}

分類した各景観構成要素の面積占有率を出した。面積占有率を算 出する手順は以下の通りである。

まず，出来上がった合成写真のサイズを整えた。次に，景観構 成要素の分類に従って，6つの画像各々に打ける各景観構成要素 の画素数を読み取り，面積の割合を\%で表した。この\%で表され た各景観構成要素の割合を各景観構成要素の一つの画像内におけ る面積占有率とした。

また，抽出した注視点を 6 つの区間に区分するために各撮影地 点の中間で区切った区間を設け（図 4), 抽出された注視点を被 験者の後方から撮影されたビデオ画像により被験者の同時刻の存 在区間を判別した。

\section{3. 実験結果及び考察 \\ （1）全被験者の歩行特性}

全被験者のアイマークデータ収集区間の歩行時間, 平均歩行速 度を表 1 に示す。歩行距離は一律 $24 \mathrm{~m}$ である。最大約 2 倍の差 が歩行速度には見られた。

被験者は全員，平橋のある経路を選択した。アンケートでもそ の動機として「橋を渡りたかった」「橋の上から風景を見たかっ た」など，橋に関する理由を挙げていた。また，水面に関する回 答で，「水に近づきたかった」「橋の上からの景色を見たかった」 などが得られており，経路選択の動機と思われる回答が得られた。 さらに，「奥の橋を見て，手前の橋之両方渡りたいと思い選んだ」 といった平橋通過後の経路選択に関わる回答も得られた。

\section{(2) 注視時間}

(i ) 平均注視時間及び注視時間分布

全被験者の注視一回あたりの注視時間の平均值と標準誤差を図 5 に示す。縦軸に平均注視時間（秒）を取り，横軸に分類した景 観構成要素を並べた。全てが $0.15 〜 0.2 \mathrm{sec}$ の間に収まっている。

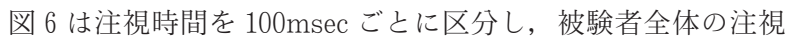
時間の頻度分布を各景観構成要素 (注視対象) に対して表したも のである。横軸には 0.1 秒で級分した時間帯を, 縦軸にはそれぞ れの注視時間区分ごとの全注視時間に対する割合を注視率として 示している。景観構成要素に関わらず注視の最大発生頻度は $100 \mathrm{msec}$ 台である。樹木名板や説明板は $300 \mathrm{msec}$ 台の注視時間 の出現頻度がやや高いが, 平均注視時間からは景観構成要素によ る違いは見られず, 注視時間分布にも景観構成要素による差はな かった。また，苑路の歩行所要時間には被験者間で最大約 2 倍差 が存在したが， 1 注視あたりの平均注視時間には差が無かった。

(ii) 注視対象と総注視時間

注視対象によって総注視時間によ゙のような差があるかを調べる ために，全被験者の注視対象ごとの注視時間を合計した結果を図 7 に示す。

この結果から, 植物(葉)を除けば「平橋」「水面」は被験者全 員から抽出され，かつ被験者 D 以外は上位に入っており，合計 ではよく注視されたという事を示している。

そこで, これら 2 つ景観構成要素が調查対象景観の注視特性 と何らかの関わりがあるあのと見て解析を進めた。

次に，6つに分けたアイマークデー夕収集区間ごとの各景観構 成要素に対する総注視時間 $(\mathrm{sec})$ 全体を 100\%として景観要素ご との構成比を表 2 に示す。植物 (葉) は他の要素よりもはるかに多 く注視されている。橋の見え易くなる区間 2 以降から平橋を注視 する頻度は増加し, 区間 5 において最大となり, 区間 6 において $0 \%$ に落ちている。この事から平橋は植物(葉)に次いで, 区間別 に見てもよく注視されたと言え，また，平橋の面積占有率が高ま るとともに注視頻度も増加するが，平橋を渡り始める前になると あまり注視されなくなる事が言える。

水面について言える事は, 区間 $2 \sim 5$ では $3 ， 4$ 番目を常に保っ 


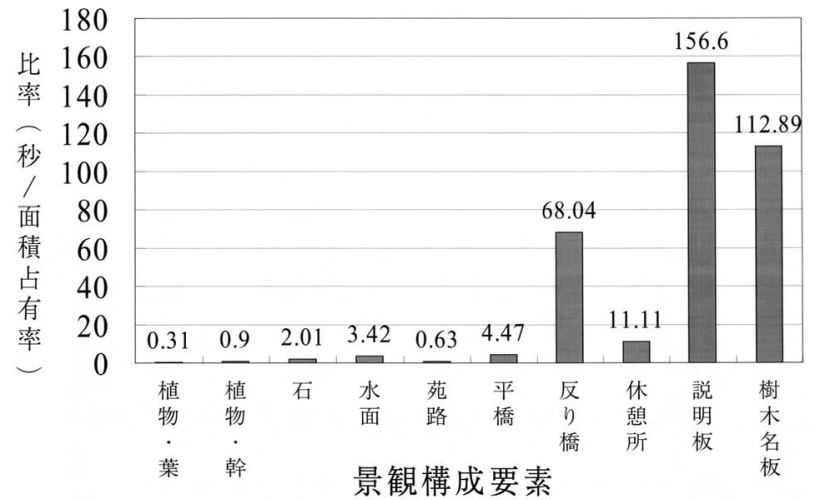

図－8 実験区間における景観構成要素の面積占有率に対する総 注視時間

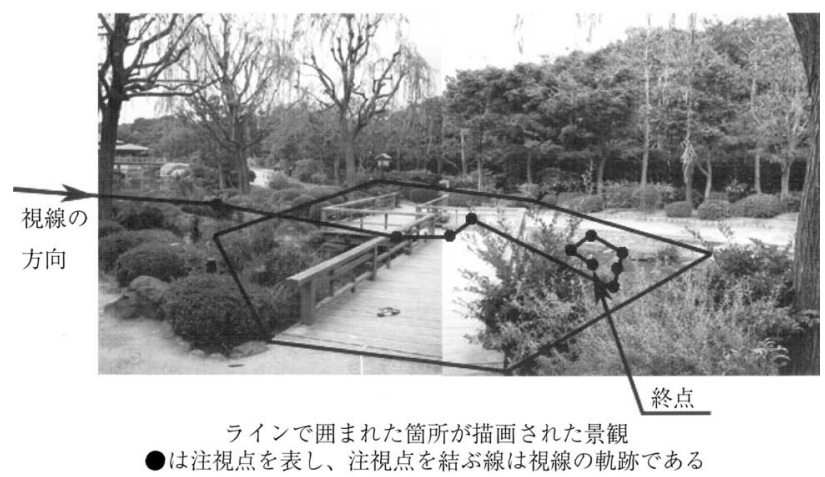

図-9 描画景観と注視点

ており，区間 6 において植物(葉)を抜いて最上位になっている事 から, 「水面」についても面積占有率の上昇が注視の頻度と関係が あり, 歩行者が近づくことにより注視頻度は急激に高まることが 言える。

\section{（3）景観構成要素の面積占有率に対する注視時間の割合}

植物 (葉)の注視時間が最も長い理由は被験者の視野を占める面 積が全景観構成要素中最大であるからとも考えられ, 水面が被験 者の歩行が進むにしたがって注視時間が増えているのも, 水面の 視野占有面積が増加していることに理由があると考えられる。

よって, 対象景観の注視特性を解明するために, 景観構成要素 の面積占有率に対する注視時間の割合を解析した。アイマークデー 夕収集区間で撮影した前方 180 度の視野面積を 100 として, 景観 構成要素ごとの面積占有率を実験区間全体のもので合計し, その 面積の 1 単位相当の注視時間を図 8 に示す。結果は, 説明板, 樹 木名板が視野面積占有率に対して相対的に高く注視されることを 示している。

景観構成要素の面積占有率に対する注視時間の割合で見ると, 平橋は人工的要素の中では注視時間は低順位である。しかし，反 り橋は説明板, 樹木名板ほどではないが, 高い注視時間となって おり,「橋」という景観属性で一まとめに考えると, 景観構成要 素「橋」は高い注視時間となっている。

また, 水面は自然要素の中では面積占有率に対する割合におい ても上位に入っている。

\section{(4) 描画実験結果}

川, 柳, 川の中にある石, 池, 春燕橋, 印月橋, 映波橋, 休噁 所, 説明板などがほぼ共通している描画された内容である。描画 された場面は分岐路地点から見ることのできる景観要素のみであっ た。

図 9 は描画実験で描かれた景観と同様の画像上に，その景観を
描画した被験者の注視点を重ねたものの一例である。画面中央の 平橋に注視点が集まっており，被験者が描画した結果と一致して いる事が分かる。

\section{4. まとめ}

平橋は全ての景観構成要素の中で植物 (葉)に次いで全被験者を 通して注視され，区間 $2 \sim 5$ に抢いて注視頻度は高い。水面につ いても同様のことが言え，さらに水面は区間 6 に扔いて最も注視 されている。これらの注視頻度が高いことは経路選択とも関係が あると考えられる。

樹木名板, 説明板が他の景観構成要素を大きく上回って上位に なり，平橋，反り橋屯「橋」という属性でまとめると，注視時間 は高くなる。反り橋はアンケートで「後で通ろうと思った」など の回答が得られていることから,「橋」は経路選択の際の重要な 判断材料であるといえる。水面は自然的要素のなかで上位となっ ている。

水は「日本の庭園の様式の基本形態であるところの地割の中 心」7)であり，橋むまた「水あれば橋あり，橋あれば必ず水があ る。水と橋とは密接の関係を有すると共に, 頗る有趣にああり美 観にあある」 ${ }^{8)}$ ので水之橋はとあに日本庭園において非常に重要 な要素である。これら2つの要素に実験区間全体に渡って注視が 集まったことは「橋」と「水」が視覚的に重要な位置にあること を示教しており，日本庭園を対象とした注視特性の一側面である と言える。

これらの結果から次の 3 点が明らかになった。 まず，景観内の異質な要素が注視されるという事である。

次に, 経路選択の動機の対象となる景観構成要素は注視頻度が 高いという事である。

そして, 日本庭園では「橋」及び「水」が特徽的に注視される ということである。

今後の研究の課題としては, ある注視点から次の注視点への関 係性の解明や注視には至らない視点の動きなどの解明や，回遊式 以外の日本庭園あるいは都市公園などのフィールドにおいて本実 験之同様のアイマークレコーダを用いた散策歩行実験を行い，得 られた結果を比較対照することによって，各庭園形式及び都市公 園などの注視特性を解明することである。

\section{引用文献}

1 ）材野博司・宮岸幸正（1992）：基本構造シークエンスと行動 シークエンス景観との関係：日本建築学会計画系論文集 438, $79-85$

2 ）仲山和利・仙田満・矢田努（1998）：回遊式庭園の利用と空 間に関する研究：日本建築学会大会学術講演梗概集, 607608

3 ) 宮岸幸正・材野博司（1992）：シークエンス景観における景 観行動之空間の開放度・インパクト度との関係：日本建築学 会計画系論文集 $440,119-125$

4 ）足立哲・荒木兵一郎（1992）：屋内歩行時の視覚誘導情報へ の痴呆性老人之精神薄弱者の注視に関する実験的研究：日本 建築学会計画系論文報告集 439，55-63

5 ）木利友・岡崎甚幸（2002）：地下鉄駅舎とその仮想現実空間 に打ける探索歩行時の注視之歩行行動の比較：日本建築学会 計画系論文集 $555 ， 199-205$

6 ）進士五十八（1999）：風景デザイン 感性とボランティアの まちづくり：学芸出版社， 24

7 ）吉川需（1968）: 古庭園のみかた美と構成：第一法規出版株 式会社, 107-123

8 ）杉本文太郎（1927）：日本造庭法：威光館出版部， 198-199 